\title{
How Chinese State-Owned Enterprises Change Their Dynamics in New Product Innovation?
}

\author{
Xiaomin Zhao' \\ Ping $\operatorname{Lan}^{2}$
}

'Business School, Jilin University, P.R. of China

School of Management, University of Alaska Fairbanks, U.S.A.

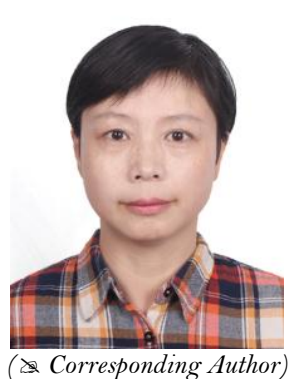

\begin{abstract}
The innovation of state-owned enterprises and its adaptation to the market competition have been in the spotlight of studies. According to the panel data form Statistics on Science and TechnologyOriented Activities of Industry Enterprises, this research measures and contrasts the new product innovation investment and performance of Chinese State-Owned Enterprises (SOEs) and nonSOEs. It reveals that market competition is a positive effect on new product innovation input and output of state-owned enterprises, as non-SOE, the relationship between competition intensity and new product innovation output of state-owned enterprises appears exponential relationship. Furthermore, it discovers that non-SOE is more sensitive to competition intensity than SOE. Under the different competitive environment, both of them play differents role on promoting development of innovation and stabilising the market.
\end{abstract}

Keywords: State-owned enterprises, Market competition, Competition intensity, New product, Innovation.

Citation | Xiaomin Zhao; Ping Lan (2017). How Chinese StateOwned Enterprises Change Their Dynamics in New Product Innovation? Asian Journal of Economics and Empirical Research, 4.(1): 25-31.

History:

Received: 29 June 2017

Revised: 4. September 2017

Accepted: 12 September 2017

Published: 18 September 2017

Licensed: This work is licensed under a Creative Commons Attribution 3.0 License $(\mathrm{cc})$ (

Publisher:Asian Online Journal Publishing Group
Contribution/Acknowledgement: Both authors contributed to the conception and design of the study.

Funding: This study received no specific financial support.

Competing Interests: The authors declare that they have no conflict of interests.

Transparency: The authors confirm that the manuscript is an honest, accurate, and transparent account of the study was reported; that no vital features of the study have been omitted; and that any discrepancies from the study as planned have been explained.

Ethical: This study follows all ethical practices during writing.

\section{Contents}

1. Introduction 26

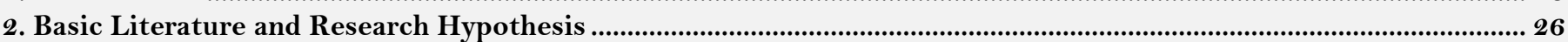

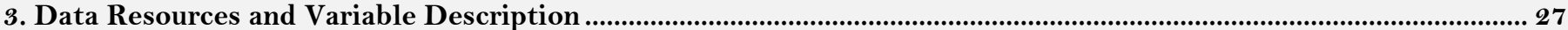

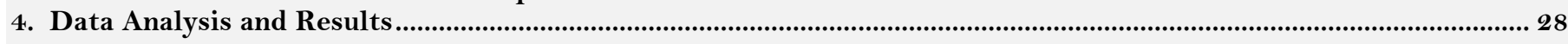

5. Conclusion

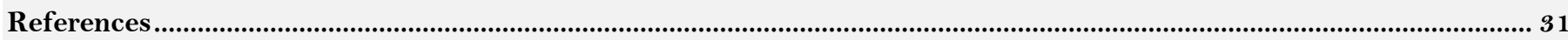




\section{Introduction}

With the increasingly fierce market competition, some state-owned enterprises (SOEs) have been navigated in a tough situation. During the 1930s, the structuralism theory proposed by Harvard School presents that the behavior of the enterprises relies on the structure of market, but it can also exert an impact on market performance, only with a competitive structure can market play an effective role in competing and maintaining the normal order in market. Therefore, the market competition intensity has an incentive effect on both input and output of new products. However, correlation theory and literatures still didn't give us a specific answer about what type should an enterprise pursue to develop the innovation of the enterprises. Some research discovered an inverted "U"-shape of the relationship between the market competition and enterprise innovation (Aghion et al., 2005; Nie et al., 2008) and some came to a conclusion that market competition can obviously influence the efficiency of the enterprise innovation activities (Bai and $\mathrm{Li}, 2006$ ) and the more fierce market competition situation is, the more input there will be provided for research project of SOEs (Zhou, 2010).In spite of drawing these conclusions, we still don't have a specific answer about whether market competition can push innovation of new products of SOEs moving forward. More further and more detailed, is the effectiveness on new product innovation of SOEs exerted by market competition the same as the effectiveness on that of non-SOEs? And SOEs or non-SOEs, which is more sensitive to market competition?

According to the panel data from Statistics on Science and Technology-Oriented Activities of Industry Enterprises (SSTAIE) from 2006 to 2011, there are two aspects we can use to measure how market competition can affect the new product innovation of SOEs. First, we could measure the impact on input and output of the new product of SOE exerted by market competition. Second, we can investigate characteristics of innovation behavior and performance of the SOEs in terms of new products innovation of the non-SOEs.

\section{Basic Literature and Research Hypothesis}

The basic view of Schumpeter's Hypotheses is that there is a tightened tie between the innovation and monopoly. Further, high degree of market concentration will accelerate the research and development work of enterprises. However, some empirical analysis that have been conducted by subsequent scholars show that there isn't a consequent relation between innovation and market concentration which also means that larger business scale will facilitate innovation is not doomed (Nickell, 1996). But Aghion et al. (2005) find a theory that the relationship between market competition intensity (Lerner's index) and innovation (Patent number) is an inverted-“U” shape. Market competition has a significant impact on the efficiency of the new product innovation of enterprises (Bai and Li, 2006). The enterprise that belongs to the industry of high degree of the market competition takes obviously faster steps to practice innovation than the enterprises belonging to the monopoly industry. while market competition intensity is continuously strengthened, the same input of research and development of the new product will contribute to more sales income from new product and patents invention. On the contrary, as for higher concentration of market it won't enhance the efficiency of the enterprise innovation activity it will reduce the efficiency of using the innovation resources because of being lack of competition.

\subsection{Attribution Study of Market Competition and Input of New Product Innovation}

Scholars have made many researches to find the reasons why market competition can influence the enterprise innovation. Hart (1983) earlier pushed forward that indolent behaviors of management will be declined by the competition of product market in terms of his formal analysis and research. But Scharfstein (1988) found that the fiercer the market competition will be, the more indolently the management will act. Raith (2003) found that product market competition promotes the effort level of management. Similarly, many researches find that there is a close connection between the competition of product market and enterprise innovation. When an enterprise has a principal-agent relation, the negative impact of the delegation will reduce by the market competition, which will force enterprise to practice innovation more positively (Fond and Park, 1999). The theory of competition emphasizes the stimulating influence from competition mechanism and the external condition that has an impact on enterprises development and survival and also reveals that market competition can attach more efficiency to the market mechanism in allocating innovation resources. Competition is a sustaining drive of technology innovation of enterprises. The essential factor of enterprise innovation should be found in the essential market and the innovation products should come into reality by market products competition. A fierce market competition situation will provide enterprise with more powerful external pressure. Enterprises need to unremittingly pursue technology innovation and enhance their core competitiveness in order to their own survival and development. In this way, competition is an important reason for stimulating enterprise innovation.

\subsection{Influence of New Product Innovation of SOEs by Market Competition}

From the view of property rights, the SOE is different from the non-SOE. However, compared with property rights theory which stresses the stimulating influence from residual control right competition theory thinks that even though residual control right can be smoothly aliened, the problems of floating efficiency of SOEs is still existing. The key to the low efficiency of SOEs is about that managers of SOEs lack enough stimulation from competition and the market competition environment which can provide them with an effective stimulation and a strong constraint (Lin, 1995). Market competition is the fundamental premise to succeed in SOEs reform. The reform of property rights that are undergoing in the situation where managers of SOEs lack enough stimulation from competition can't overcome the problems such as information asymmetry of SOEs, incompatibility of stimulating mechanism and unequal responsibility and so on so that the efficiency of SOEs still cannot be promised (Lin et al., 1997). The reason for these problems is that government as delegators places too much burden from all kinds of policies on the shoulder of SOE, so that the profit rate cannot fully register the level of how hardworking SOE's managers are. SOEs managers lack enough stimulating competition; as a result, it is hard to overcome the difficulties including information asymmetry of SOEs and government and incompatibility of stimulating mechanism. The matters including enterprise budget constraint softening and violation of the SOE's management 
from the ownership rights and interest may lead to low efficiency of SOEs and loss of state-owned assets, which will be difficult to avoid (Lin et al., 1997). Similarly, in the beyond property rights theory which stresses on competition mechanism, pushing manager to be hardworking by property rights reform should be premised on market competition (Liu and Li, 1998). Summarizing the above discussion, we can easily find that sufficient competition can encourage SOEs' managers to enhance their production efficiency so as to increase input and output of new product innovation. Therefore, we propose Hypothesis 1: the intensity of market competition has a positive impact on input and output of new product innovation of SOEs.

The ownership of SOE is very different from that of non-SOE. Property rights theory points out that 'absence of ownership' and 'unclaimed property' in a SOE lead to a situation where SOE's managers lack internal stimulating mechanism from property rights. As a result, SOEs are always short of money from investment in implementing technology improvement and re-equipment (Wang and Zhou, 2000). Principle-agent theory throws a light on that the problem existing in delegation and authorize in SOEs is more serious than this of non-SOEs (Xu et al., 2006; Li, 2009). Because, considering short-term employment and evolution way which means income is linked up with current performance, these managers have to value short-term profit and current performance and their position more, instead of long-term development and technology innovation for enterprises (Jia, 2002). Government officials' intervention make the relation of SOEs delegation and agency as national ownershipgovernment officials - managers (Shapiro and Willig, 1990) this kind of relation results in a mass consequence including multitasking and multiple principal-agent, besides some more serious delegation problems (Holmstrom and Milgrom, 1991). So what badly hinder input and concentration of innovation payment by SOE managers are short-term behavior of government officials, government administration intervention to SOEs, employment decisions to SOEs managers and supervising them by government apartments (Bai et al., 2004; Koppell, 2007; Li et al., 2007). Therefore, we propose Hypothesis 2: the impact that competition intensity has on input and output of SOE new product innovation is weaker than those of non-SOEs.

\subsection{Correlation between Market Competition and New Product Innovation of Enterprises}

Brazilian economist Mahmood Ali Ayoub and Portuguese economist Sven Olaf Hegstad published a research report in 1986 about "Determinant of SOE Success" that points out market competition confronting SOEs influences SOEs' performance. Australian economist, professor Tittenbrun (1996) analyzed around 85 literature reviews about property rights and enterprise performance and drew a conclusion that property rights is one of the reasons that can influence enterprise performance, but the matter of property ownership is not the root of causing performance difference, which also cannot influence performance alone. According to correlated statistics from 25 transforming countries and 3300 enterprises, Carlin et al. (2001) made a correlation analysis about enterprises performance and finally they released that the key factor that can promote the performance and enhance the efficiency of the enterprise is establishing competition mechanism(Bai and Li, 2006). Therefore, not only ownership structure but also market structure and competition intensity and other instruments have a collective impact on enterprises performance (Konings and Xavier, 2003). In terms of earlier research which shows that the relationship between the market competition and business innovation is just like an inverted "U"-shape (Aghion et al., 2005; Nie et al., 2008) we can infer that the relationship between market competition and enterprises new product innovation may be nonlinear. To a certain extent, more fierce competition intensity will drive a higher innovation level of enterprises new product; competition has an exponential impact on new product innovation of both industries and SOEs. So we have our Hypothesis 3: market competition has a positive impact on new product innovation of enterprises, but not a linear correlation.

\section{Data Resources and Variable Description}

\subsection{Variable Description}

The indicators that can be used to measure the new product innovation activities of enterprises include input and output of new product. We use "R\&D fund of new product" as indicator to measure innovation input, use new product quantity and output value of new product as an indicator to measure innovation output. The indicator we can use to measure market competition intensity includes Herfindahl-Hirschman Index (HHI) and enterprises quantity. Since it is difficult to figure the share of market of each enterprise, we use the number of enterprises above industrial average level as indicator to describe the intensity of competition in the industry. SOEs refer to stateowned and state-controlled enterprises; non-SOEs are all enterprises except SOEs. According to New product production and development by registered status from the Statistics on Science and Technology-Oriented Activities of Industry Enterprises published by the Office for National Statistics, non-SOEs include private enterprises. Macao-, Hong Kong-and Taiwan-based investment and other foreign investment ventures are in this category.

\subsection{Data Resource}

According to the SSTAIE from 2006 to 2011 and 2012 Yearbook of Statistics on Science and TechnologyOriented Activities of Industry Enterprises, we choose 39 industries as research sample. We obtain the figure of project quantity of new product by industrial sector and by SOEs, R\&D fund of new product and output value of new product from "New Products Development and Production by Industrial Sector", "New Products Development and Production by Industrial State-owned and State-controlled Enterprises". And we obtain the number of employment of state-owned enterprises and enterprise quantity from "Basic status of Enterprises by Industrial Sector", "Basic Status of SOEs and State-controlled Enterprises by Industrial Sector". By processing the data, we find that there is a big gap between 2012 statistical data and its former 6-year data from Yearbook of Statistics on Science and Technology-Oriented Activities of Industry Enterprises. For example, the number of industrial enterprise is about 40,000 from 2005 to 2010, which year-on-year growth rate is around $10 \%$, however, this number of 2011 stands at 325735, even 6 times year-on-year growth rate as before. We guess probably changing the statistical caliber causes this data mutation. In order to prevent these mass data from destroying our 
data accuracy, we won't use data of 2011. Besides, we also rule out the 6th industry (Mining industry of other minerals) and the 36 th industry (Wasting resource and waste material recycling and reprocessing industry) which are lack of some data. Finally, we obtain the panel data from 37 industries from 2005 to 2010.

\subsection{Descriptive Statistics}

Table 1 is the descriptive statistics of the major variable

Table-1. The Descriptive statistics of the major variable $(2005 \sim 2010)$

\begin{tabular}{|c|c|c|c|c|c|c|c|}
\hline variable & Definition & unit & observed value & $\min$ & $\max$ & mean & $\mathbf{S}$ \\
\hline $\begin{array}{l}\text { Market competition } \\
\text { intensity }\end{array}$ & $\begin{array}{l}\text { Enterprise number of each } \\
\text { industry }\end{array}$ & & 222 & 63 & 3646 & $1.01 \mathrm{E} 3$ & 851.87 \\
\hline \multirow{3}{*}{$\begin{array}{l}\text { Quantity of new } \\
\text { products }\end{array}$} & new product number & & 221 & 10 & 25850 & $3.29 \mathrm{E} 3$ & 5064.81 \\
\hline & $\begin{array}{l}\text { Quantity of new products of } \\
\text { SOEs }\end{array}$ & & 222 & 10 & 13311 & $1.49 \mathrm{E} 3$ & 2424.44 \\
\hline & $\begin{array}{l}\text { Quantity of new products of } \\
\text { non-SOEs }\end{array}$ & & 222 & O & 18762 & $1.79 \mathrm{E} 3$ & 3000.91 \\
\hline \multirow[t]{3}{*}{$\begin{array}{l}\text { R\&D funds of new } \\
\text { product }\end{array}$} & $\begin{array}{l}\text { Total R\&D Fund of new } \\
\text { product of industry }\end{array}$ & $\begin{array}{l}\text { Million } \\
\text { yuan }\end{array}$ & 2.22 & 14.20 & $7.16 \mathrm{E} 4$ & $7.64 \mathrm{E} 3$ & $1.33 \mathrm{E} 4$ \\
\hline & $\begin{array}{l}\text { R\&D funds of new product } \\
\text { of SOEs }\end{array}$ & $\begin{array}{l}\text { Million } \\
\text { yuan }\end{array}$ & 2.22 & 3.66 & $5.03 \mathrm{E} 4$ & $3.29 \mathrm{E} 3$ & $6.84 \mathrm{E} 3$ \\
\hline & $\begin{array}{l}\mathrm{R} \& \mathrm{D} \text { funds of new product } \\
\text { of non-SOEs }\end{array}$ & $\begin{array}{l}\text { Million } \\
\text { yuan }\end{array}$ & 2.22 & O & $4.90 \mathrm{E} 4$ & $4.35 \mathrm{E} 3$ & $8.12 \mathrm{E} 3$ \\
\hline \multirow[t]{3}{*}{$\begin{array}{l}\text { Output value of new } \\
\text { product }\end{array}$} & $\begin{array}{l}\text { Total Output value of new } \\
\text { product of industry }\end{array}$ & $\begin{array}{l}\text { Million } \\
\text { yuan }\end{array}$ & 2.21 & 1.00 & $1.67 \mathrm{E} 6$ & $1.29 \mathrm{E} 5$ & $2.55 \mathrm{E} 5$ \\
\hline & $\begin{array}{l}\text { Output value of new product } \\
\text { of SOEs }\end{array}$ & $\begin{array}{l}\text { Million } \\
\text { yuan }\end{array}$ & 2.20 & 1.00 & $1.22 \mathrm{E} 6$ & $5.62 \mathrm{E} 4$ & $1.45 \mathrm{E} 5$ \\
\hline & $\begin{array}{l}\text { Output value of new product } \\
\text { of non-SOEs }\end{array}$ & $\begin{array}{l}\text { Million } \\
\text { yuan }\end{array}$ & 2.22 & O & $1.14 \mathrm{E} 6$ & $7.27 \mathrm{E} 4$ & $1.55 \mathrm{E} 5$ \\
\hline
\end{tabular}

Source: Statistics on Science and Technology-Oriented Activities of Industry Enterprises (SSTAIE)

\section{Data Analysis and Results}

\subsection{Influence on the New Product Innovation of SOE and Non-SOE by the Market Competition}

Considering innovation behavior and performance of non-SOEs, we focus upon the impact on new product innovation of SOEs exerted by market competition. And we set this formulation:

$$
Y_{i t}=a_{i t}+\beta_{i t} X_{i t}^{\prime}, \quad i=1,2,3, \cdots \cdots, 39, t=2005,2006, \cdots \cdots \cdot, 2010
$$

$Y_{i t}$ is input or output of enterprises new product innovation; $X_{i t}^{\prime}$ is market competition.

Table-2. The influence of market competition intensity on new products innovation of SOE and non-SOE

\begin{tabular}{|c|c|c|c|c|c|c|c|}
\hline \multirow[t]{2}{*}{$\begin{array}{l}\text { Data analysis } \\
\text { model }\end{array}$} & \multirow[t]{2}{*}{$\begin{array}{l}\text { Independent } \\
\text { variable }\end{array}$} & $\begin{array}{l}\text { R\&D } \\
\text { funds of } \\
\text { new } \\
\text { product } \\
\text { of SOEs }\end{array}$ & $\begin{array}{l}\text { R\&D } \\
\text { funds of } \\
\text { new } \\
\text { product } \\
\text { of non- } \\
\text { SOEs }\end{array}$ & $\begin{array}{l}\text { New } \\
\text { product } \\
\text { quantity } \\
\text { of SOEs }\end{array}$ & $\begin{array}{l}\text { New } \\
\text { product } \\
\text { quantity } \\
\text { of non- } \\
\text { SOEs }\end{array}$ & $\begin{array}{l}\text { Output } \\
\text { value of } \\
\text { new } \\
\text { products } \\
\text { of SOEs }\end{array}$ & $\begin{array}{l}\text { Output } \\
\text { value of } \\
\text { new } \\
\text { products } \\
\text { of non- } \\
\text { SOE }\end{array}$ \\
\hline & & $\begin{array}{l}\beta \\
\text { (t-value) }\end{array}$ & $\begin{array}{l}\beta \\
\text { (t-value) }\end{array}$ & $\begin{array}{l}\beta \\
\text { (t-value) }\end{array}$ & $\begin{array}{l}\beta \\
\text { (t-value) }\end{array}$ & $\begin{array}{l}\beta \\
\text { (t-value) }\end{array}$ & $\begin{array}{l}\beta \\
\text { (t-value) }\end{array}$ \\
\hline \multirow{2}{*}{$\begin{array}{l}\text { constant } \\
\text { coefficient } \\
\text { model (cross- } \\
\text { section } \\
\text { weight) } \\
\end{array}$} & constant term & $\begin{array}{l}-0.049 \\
(-3.87 * * *)\end{array}$ & $\begin{array}{l}-0.088 \\
(-7.63 * * *)\end{array}$ & \begin{tabular}{|l|}
-0.123 \\
$\left(-7.06^{* * *}\right)$ \\
\end{tabular} & $\begin{array}{l}-0.074 \\
(-5.62 * * *) \\
\end{array}$ & $\begin{array}{l}-0.03 \\
\left(-4.49^{* * *}\right) \\
\end{array}$ & $\begin{array}{l}-0.09 \\
(-6.76 * * *) \\
\end{array}$ \\
\hline & $\begin{array}{l}\text { Market } \\
\text { competition } \\
\text { intensity }\end{array}$ & $\begin{array}{l}0.456 \\
\left(31.26^{* * *}\right)\end{array}$ & $\begin{array}{l}0.555 \\
\left(28.22^{* * *}\right)\end{array}$ & \begin{tabular}{|l}
0.506 \\
$(23.64 * * * *)$
\end{tabular} & $\begin{array}{l}0.608 \\
\left(30.08^{*} * *\right)\end{array}$ & $\begin{array}{l}0.387 \\
\left(47.42^{* * *}\right)\end{array}$ & $\begin{array}{l}0.47 \\
\left(20.28^{* * *}\right)\end{array}$ \\
\hline \multirow{2}{*}{ Fitting effect } & $R^{2}$ & 0.82 & 0.784 & 0.72 & 0.804 & 0.91 & 0.65 \\
\hline & F-value & $977.3^{*} * * *$ & 796.4**** & $559.0^{\text {******* }}$ & $904.86^{* * * * *}$ & 2249 **** & $411.2^{* * * *}$ \\
\hline
\end{tabular}

Because the fitting results of the constant coefficient model conform to the requirements $\left(\mathrm{R}^{2}>0.6, \mathrm{~F}\right.$-value is significant on 0.01 level), we omit variable intercept - time model and variable intercept - industry model. In the constant coefficient model, market competition intensity correlates positively with the R\&D funds of new product innovation of SOEs $(\beta=0.456$, t-test $=31.26$, sig. $<0.01)$,new product quantity of SOEs $(\beta=0.506$, t-test $=$ 23.64 , sig. $<0.01$ and output value of new products of $\operatorname{SOEs}(\beta=0.387, \mathrm{t}$-test $=47.42$, sig. $<0.01)$ as shown in Table 2. Therefore, Hypothesis 1 is established.

Among them: the model coefficient data are coefficient $=0.456$ in showing the correlation between market competition intensity and the R\&D funds of new product innovation of SOEs (t-test $=31.26$, sig. $<0.01$ ), and coefficient $=0.555$ in showing the correlation between market competition intensity and the R\&D funds of new product innovation of non-SOEs $(t$-test $=28.221$, sig. $<0.01)$. This comparison reveals with increasingly fierce market competition, the investment in new product innovation will also increase. Market competition has a positive 
influence on both SOEs and non-SOEs, especially the non-SOEs. As shown in Figure 1: in a low competition environment, R\&D funds of new product innovation of SOEs is slightly more than non-SOEs, while, in a high competition environment, R\&D funds of new product innovation of non-SOEs is slightly higher.

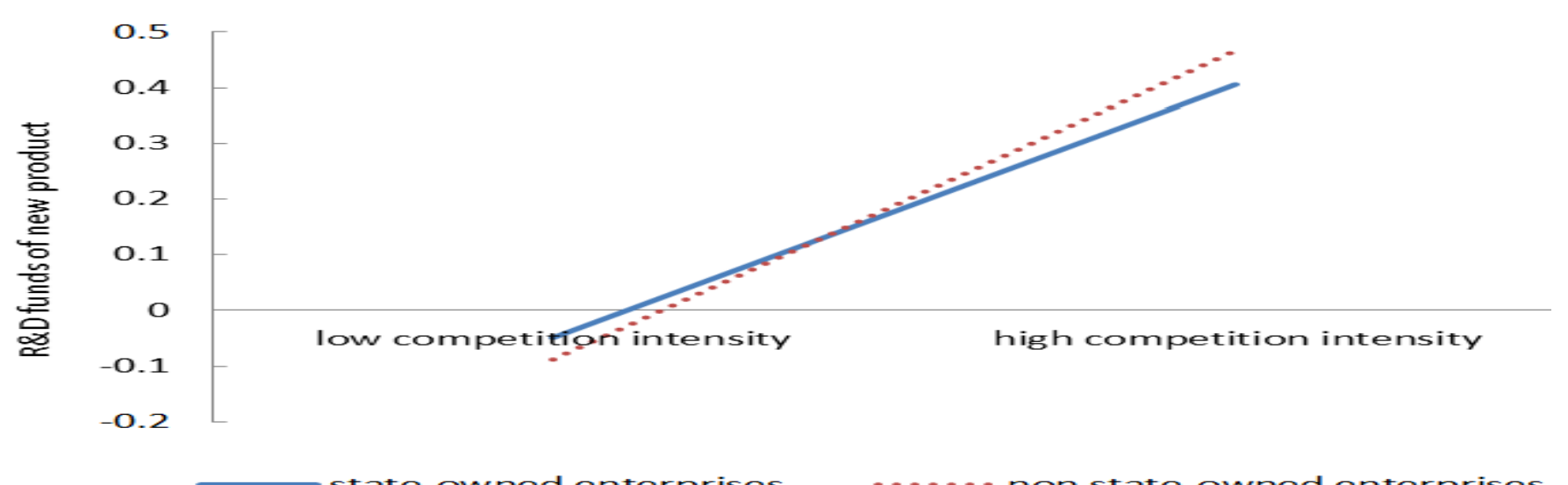

Figure-1. The different behavior of SOEs and non-SOEs investing in new product in different situation

Source: the panel data analysis from Statistics on Science and Technology-Oriented Activities of Industry Enterprises

The model coefficient data are coefficient $=0.506$ in showing the correlation between market competition intensity and new product quantity of SOEs (t-test $=23.64$, sig. $<0.01$ ), and coefficient $=0.608$ in showing the correlation between market competition intensity and new product quantity of non-SOEs ( $t$-test $=30.08$, sig. $<0.01$ ). This comparison reveals that with increasingly fierce market competition, the new product quantity will also increase and the increase of new product of non-SOEs will be a little bit higher than SOEs. As we can draw a conclusion from Figure 2 that the number of new product of SOEs is always smaller than non-SOEs, and under a high competition environment, this gap will be wider.

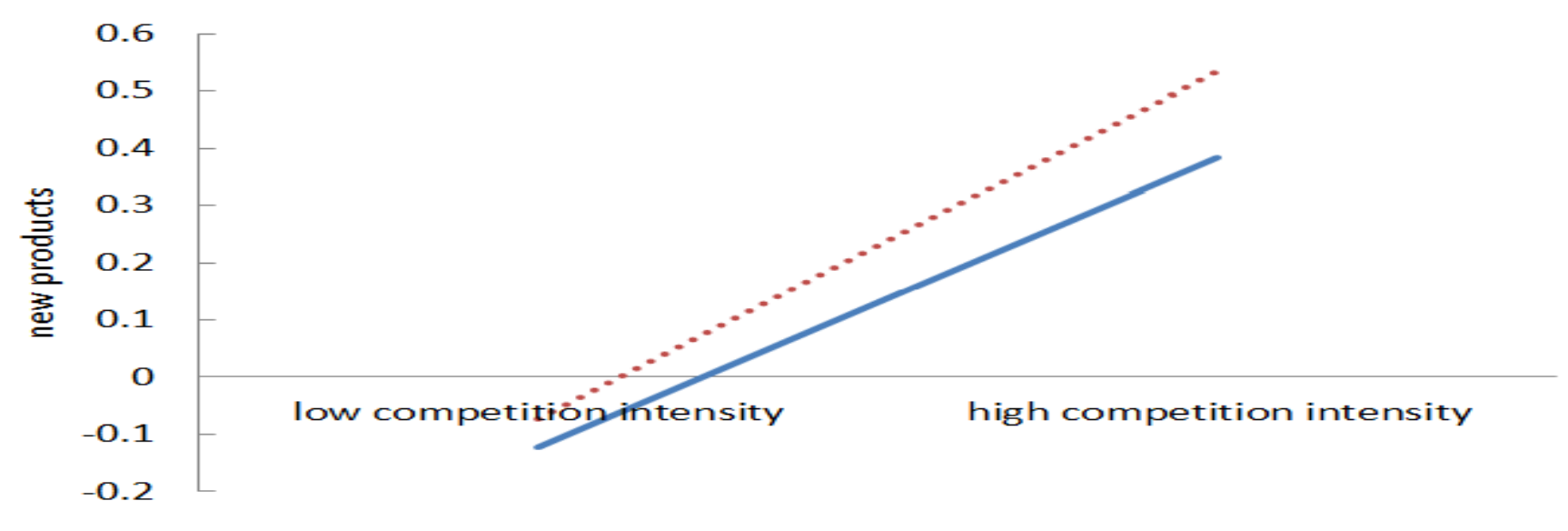

state-Owned enterprises $\ldots . . . .$. non state-Owned enter
Figure-2. The different behavior of SOEs and non-SOEs in the part of new product quatity in different situation

Source: the panel data analysis from Statistics on Science and Technology-Oriented Activities of Industry Enterprises

The model coefficient data are coefficient $=0.387$ in showing the correlation between market competition intensity and output value of new products of SOEs ( $t$-test $=47.42$, sig. $<0.01)$, and coefficient $=0.47$ in showing the correlation between market competition intensity and output value of new product of non-SOEs $(\mathrm{t}$-test $=20.28$, sig. $<0.01$ ). The comparison is shown in the Figure 3 that under a low competition environment, output value of new products of SOEs is a little more than non-SOEs, while with increasingly fierce market competition, the position of these two will exchange.

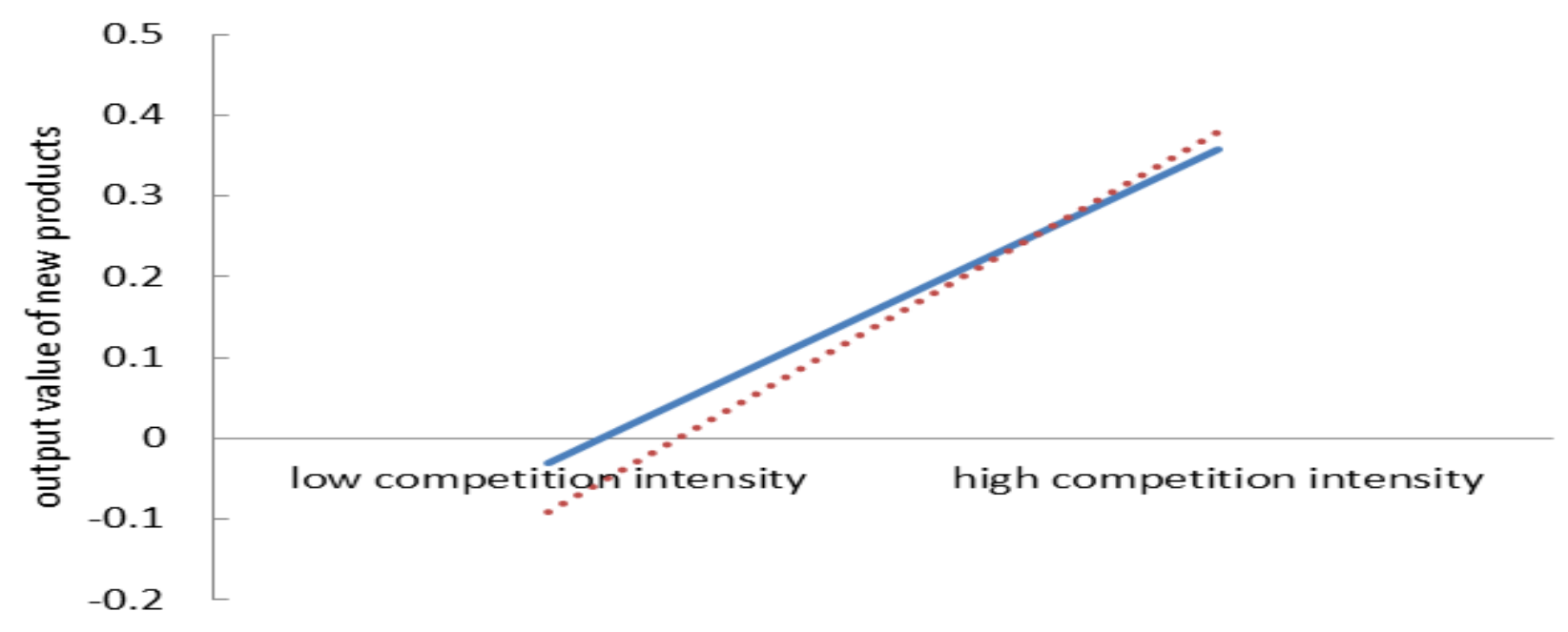

Figure-3. The difference from output value of new products of SOEs and non-SOEs in different situation Source: the panel data analysis from Statistics on Science and Technology-Oriented Activities of Industry Enterprises 
No matter on the part of R\&D funds of new product, new product quantity or output value of new product, the correlation between market competition intensity and SOEs is bigger than non-SOEs as shown in Table 2 . From Figure 1,2 and 3, we can clearly find that the slope of non-SOE line is larger than SOE line, so we can draw a conclusion that the non-SOE is much more sensitive than the SOE. Therefore, Hypothesis 2 is established.

\subsection{The Correlation of Market Competition and New Product Innovation of SOEs}

Some scholar such as Aghion et al. (2005) and Nie et al. (2008) and so on think that the correlation relation between market competition and enterprise innovation is not linear but curvilinear.

They consider this correlation as an inverted-U shape. So, according to these former researches, we set following formula:

$$
Y_{i t}=a_{i t}+\beta_{1 i t} X_{i t}^{\prime}+\beta_{2 i t} X_{i t}^{\prime 2}+U_{i t}, \quad i=1,2,3, \cdots \cdots, 39, \quad t=2005,2006, \cdots \cdots, 2010
$$

$Y_{i t}$ is input or output of enterprises new product innovation; $X_{i t}^{\prime}$ is market competition.

Table-3. Panel data analysis of influence on new product innovation of SOEs by market competition

\begin{tabular}{|c|c|c|c|c|c|c|c|c|c|}
\hline \multirow{2}{*}{$\begin{array}{l}\text { Data } \\
\text { analysis } \\
\text { model }\end{array}$} & \multirow{2}{*}{$\begin{array}{l}\text { Independent } \\
\text { variable }\end{array}$} & \multicolumn{2}{|c|}{$\begin{array}{l}\text { The total output } \\
\text { value of new } \\
\text { products }\end{array}$} & \multicolumn{2}{|c|}{$\begin{array}{l}\text { Output value of } \\
\text { new products of } \\
\text { SOEs }\end{array}$} & \multicolumn{2}{|c|}{$\begin{array}{l}\text { The total quantity } \\
\text { of new product }\end{array}$} & \multicolumn{2}{|c|}{$\begin{array}{l}\text { New product } \\
\text { quantity of SOEs }\end{array}$} \\
\hline & & $\beta$ & $\begin{array}{l}\text { t-value } \\
\text { prob. }\end{array}$ & $\beta$ & $\begin{array}{l}\text { t-value } \\
\text { prob. }\end{array}$ & $\beta$ & $\begin{array}{l}\text { t-value } \\
\text { prob. }\end{array}$ & $\beta$ & $\begin{array}{l}\text { t-value } \\
\text { prob. }\end{array}$ \\
\hline \multirow{3}{*}{$\begin{array}{l}\text { constant } \\
\text { coefficient } \\
\text { model } \\
\text { (cross- } \\
\text { section } \\
\text { weight) }\end{array}$} & constant term & -0.278 & -23.71 & -0.07 & \begin{tabular}{|l}
$-12.43^{* * * *}$ \\
$(0.0000)$ \\
\end{tabular} & -0.226 & -16.76 & -0.118 & $\begin{array}{l}-8.60^{* * * *} \\
(0.0000)\end{array}$ \\
\hline & $\begin{array}{l}\text { Market } \\
\text { competition } \\
\text { intensity } \\
\end{array}$ & 0.397 & $\begin{array}{l}27.67^{* * * *} \\
(0.0000)\end{array}$ & 0.354 & $\begin{array}{l}55.63^{* * * *} \\
(0.0000)\end{array}$ & 0.563 & $\begin{array}{l}24.49^{* * * *} \\
(0.0000)\end{array}$ & 0.506 & $\begin{array}{l}21.05^{* * * *} \\
(0.0000)\end{array}$ \\
\hline & $\begin{array}{l}\text { The intensity } \\
\text { of competition } \\
\text { squared }\end{array}$ & 0.240 & $\begin{array}{l}22.18^{* * *} \\
(0.0000)\end{array}$ & 0.048 & $\begin{array}{l}9.92^{* * *} \\
(0.0000)\end{array}$ & 0.206 & $\begin{array}{l}11.04 * * * \\
(0.000)\end{array}$ & 0.037 & $\begin{array}{l}1.87^{*} \\
(0.0623)\end{array}$ \\
\hline \multirow[b]{2}{*}{ Fitting effect } & $R^{2}$ & \multicolumn{2}{|l|}{0.88} & \multicolumn{2}{|l|}{0.941} & \multicolumn{2}{|l|}{0.75} & \multicolumn{2}{|l|}{0.817} \\
\hline & \begin{tabular}{|l|}
$\mathrm{F}$ \\
Prob.
\end{tabular} & \multicolumn{2}{|c|}{$\begin{array}{l}813.12^{* * * *} \\
(0.0000)\end{array}$} & \multicolumn{2}{|l|}{$\begin{array}{l}1716^{* * * *} \\
(0.0000)\end{array}$} & \multicolumn{2}{|l|}{$\begin{array}{l}323 * * * * \\
(0.000)\end{array}$} & \multicolumn{2}{|c|}{$\begin{array}{l}489.3^{* * * *} \\
(0.000)\end{array}$} \\
\hline
\end{tabular}

Because the constant coefficient model considers influence from both industries and time and also has a stricter requirement to the data, we mainly take the reference from the analyzing results from this model. All fitting results of these constant coefficient model are very suitable $\left(\mathrm{R}^{2}>0.7, \mathrm{~F}\right.$-value is significant on 0.01 level.) shown in the Figure 3. Therefore, we omit variable intercept - time model and variable intercept - industry model.

In these four models, the square of market competition intensity is always positive, correlated coefficient is significant on 0.01 level, which means the relationship between the market competition and output value of the new product is a normal "U"-shaped, also the relationship between the new product quantity and market competition. This conclusion is inconsistent with the former conclusion that the relationship between market competition intensity and innovation is an inverted-"U" shape (Aghion et al., 2005; Nie et al., 2008).

In the constant coefficient model, the inflection point in the inverted-"U" relation between market competition intensity and output value of new product is -0.93 , we can find that according to the indicator on the industry competition intensity, the following 8 industries locates on the right of the inflection point, Industry 2 (Petroleum and Natural Gas Extraction Industry), Industry 4 (Ferrous Metals Mining and Processing Industry),Industry 4 (colorful Metals Mining and Processing Industry),Industry 5(nonmetal minerals mining and processing industry), industry 10 (tobacco processing industry), industry 22 (chemical fiber), industry 38 (gas production and supply), industry 39 (water production and supply). That indicates in these industries the output value of new products will not fall with a decreasing market competition. As a view of sector characters, most of these industries are in the field of country fundmental and limited industries (which SOEs accounts for more than 30\%). Other 29 industries locate on the left of the inflection point, which indicates that their output value will be larger with a increasing market competition and the growth pattern is exponential but not linear. The inflection point in the inverted-"U" relation between market competition intensity and quantity of new product is -1.36 . Compared with the indicators of different industries, we find that all industries are on the left of the inflection point (the range of the standard value of the market competition by industry is $>-1.1)$, that shows the market competition intensity has a respectively positive correlation with the quantity of new product project and the growth pattern is exponential but not linear.

In the constant coefficient model of the market competition influence on quantity of new product project of SOEs and output value of new product of SOEs, the square of market competition are both positive value and coefficients are both significant on 0.01 level, which means the relationship between the market competition intensity and quantity of new product project of SOEs, as well the relationship between the market competition intensity and output value of new product of SOEs, is a normal-"U" shape. This conclusion is similar to the normal-"U" shape discovered in the relationship between the market competition and innovation product of the industrial sector. Considering the inflection point of the U-shape, we find that the inflection point of the U-shape of market competition and output value of new product of SOEs is -3.688 , which of the market competition and quantity of new product project of SOEs is -6.838 , all indicators of market competition from different industries locate on the right of the inflection point(the range of the standard value of the market competition by industry is $>-1.1$ ), this means the market competition intensity has a respectively positive correlation with the quantity of new product project of SOEs and 
output value of new product of SOEs and the growth pattern is exponential but not linear. Therefore Hypothesis 3 is established.

\section{Conclusion}

Some scholars still do not think highly of the development and adaption of SOEs in a competitive environment (Tan et al., 2005; Koppell, 2007; Li et al., 2007). However, in terms of the non-SOEs input and output of new product innovation, we have analyzed different behavior of SOE new product innovation in different level of market competition intensity, and the result reveals that market competition intensity has a positive impact on new product innovation of both SOEs and non-SOEs, which both adapt the new environment by increasing input and output of innovation under the competitive pressure. What is different is that non-SOEs is more sensitive to market competition, which also means with increasingly fierce market competition, the increase of input and output of innovation of the non-SOEs will be a little bit higher than SOEs. Given that the contrast of the innovation behavior between the SOEs and non-SOEs, we find that first, in a situation with a low market competitive intensity, the main new product innovation of one industry is contributed by the SOEs. In this kind of industries, it is SOEs that promote development of new product innovation.

Considering of society stability, market control and maintaining domestic economy peaceful and stable development, SOEs cannot disappear completely, that the Chinese government allow the formation of a variety of industrial ownership existing is considered as a wise and right policy (He, 2005). SOEs should play an important role in market competition by cooperating with other ownership enterprises in pointing out the direction of the market development and pushing society moving forward.

\section{References}

Aghion, P., Bloom, N., R. Blundell, Griffith, R. and Howitt, P., 2005. Competition and innovation: An inverted u relationship. Quarterly Journal of Economies, 120(2): 701-728. View at Google Scholar

Bai, C., Y. Du, Z. Tao and Y. Quan, 2004. Local protectionism and Industrial concentration in China. Overall trend and important factors. Economic Research Journal(4): 29-40.

Bai, M. and G. Li, 2006. Market competition and innovation: Schunpeter's hypothesis and its empirical verification. China Soft Science Magazine(11): 15-21.

Carlin, W., S. Fries, M. Schaffer and P. Seabright, 2001. Competition and enterprise performance intransition economies evidence from a cross-country survey. Social Science Electronic Publishing(4): 561-562.

Fond, M. and C. Park, 1999. The effect of competition on CEO turnover. Journal of Accounting and Economics, 27(1): 35-56. View at Google Scholar | View at Publisher

Hart, O., 1983. The market mechanism as an incentive scheme. Bell Journal of Eeonomies, 14(2): 366-382. View at Google Scholar | View at Publisher

He, X., 2005. The formation of new national socialist economics. M/OL. Retrieved from http://www.caogen.com/blog/Infor_detail.aspx?ID=32\&articleId=10135.

Holmstrom, B. and P. Milgrom, 1991. Multitask principal- agent analysis: Incentive contracts, asset ownership and job design. Journal of Law, Economics, and Organization, 7(Special Issue): $24-52$. View at Google Scholar $\mid$ View at Publisher

Jia, X., 2002. China's reform of the multi-layer agent of state-owned enterprises and its choice. Comparative Economic \& Social System(6): 69-76.

Konings, J. and A. Xavier, 2003. Firm performance and selection in an emerging Economy: Micro Evidence from Slovenia. Royal Economic Society Annual Conference.

Koppell, J.G.S., 2007. Political control for China's state-owned enterprises: Lessons from America's Experience with hybrid organizations. Governance, 20(2): 255-278. View at Google Scholar | View at Publisher

Li, X., 2009. Under the system environment constraint state-owned enterprise: Governance mechanism selection research. HnagZhou: Zhejiang Industry and Commerce University.

Li, Y., Y. Liu and F. Ren, 2007. Product innovation and process innovation in SOEs: Evidence from the Chinese transition. Journal of Technology Transfer, 32(1-2): 63-85. View at Google Scholar | View at Publisher

Lin, Y., 1995. The core of the SOE reform is creating competition. Environment Reform(3): 17-28.

Lin, Y., F. Cai and Z. Li, 1997. Full information and the reform of state-owned enterprises. Shanghai: Shanghai Joint Publishing Press \& Shanghai People's Publishing House.

Liu, S. and J. Li, 1998. Beyond property rights and enterprise performance. Economic Research Journal(8): 3-12.

Nickell, S., 1996. Competition and corporate performance. Journal of Political Economy, 104(4): 724-746. View at Google Scholar

Nie, H., S. Tan and Y. Wang, 2008. Innovation, enterprise scale and market competition: Based on the analysis of Chinese enterprise level panel data. Journal of World Economy, 31(7): 57-66.

Raith, M., 2003. Competition, risk and managerial incentives. American Economic Review, 93(4): 1425-1436. View at Google Scholar $\mid$ View at Publisher

Scharfstein, D., 1988. Product-market competition and managerial slack. RAND Journal of Economies, 19(1): 147-155. View at Google Scholar View at Publisher

Shapiro, C. and R. Willig, 1990. On the antitrust treatment of production joint ventures. Journal of Economic Perspectives, 4(3): 113-130. View at Google Scholar | View at Publisher

Tan, J., Y. Luo and O. Shenkar, 2005. Entrepreneurial strategies in a transitional economy: Chinese state and non-state enterprises compared and contrasted. International Journal of Enterpreneurship and Innovation Management, 5(5/6): 518-539. View at Google Scholar | View at Publisher

Tittenbrun, J., 1996. Private versus public enterprises. London: Janus Publishing Company.

Wang, Z. and Y. Zhou, 2000. The system arrangement of technology innovation. Science and Technology Progress and Policy, 17(1 1): 6466.

Xu, L., Y. Xin and G. Chen, 2006. Ownership concentration and check-and-balance ownership structure and its effects on business performance. Economic Research Journal(1): 90-100.

Zhou, Q., 2010. Double tasking, jointly delegation and innovation motivation of state-owned enterprise. Jinan University, 02 (1). 